\title{
Influence of the mineral content of the seston on tropical cladocerans of a marginal lake
}

\author{
Influência do contéudo mineral do seston em \\ cladóceros tropicais de uma lagoa marginal
}

Claudia Fileto ${ }^{1}$, Raoul Henry ${ }^{1}$, Marlene Sofia Arcifa ${ }^{2}$ and Rosa Antonia Romero Ferreira ${ }^{1}$

${ }^{1}$ Departamento de Zoologia, Instituto de Biociências, Universidade Estadual Paulista - UNESP,

Campus Botucatu, Rubião Jr., s/nº, CEP 18618-000, Botucatu, SP, Brazil

e-mail: cfileto@hotmail.com,rhenry@ibb.unesp.br, rosantonia@hotmail.com

${ }^{2}$ Faculdade de Filosofia, Ciências e Letras de Ribeirão Preto, Departamento de Biologia,

Universidade de São Paulo - USP, Av. Bandeirantes, 3900, CEP 14040-901, Ribeirão Preto, SP, Brazil

email: marcifa@usp.br

\begin{abstract}
Aim: Bioassays were carried out seasonally to evaluate individual growth and reproduction of cladocerans, from a marginal lake, with the addition of nitrogen $(\mathrm{N})$, phosphorus $(\mathrm{P})$, and both $\mathrm{N}$ and $\mathrm{P}$ to natural seston; Methods: Cohorts originated from cultivated females were submitted to the following treatments: 1) lake seston, 2) lake seston + P, 3) lake seston $+N$, and 4) lake seston + NP; Results: The sestonic $\mathrm{C}: \mathrm{P}$ and $\mathrm{C}: \mathrm{N}$ molar ratios were always high and limiting, according to threshold ratios estimated for temperate lakes. P addition to seston enhanced the growth rates of one species, $D$. birgei. A significant higher growth rate of $B$. longirostris was found in the seston enriched with $\mathrm{N}$ compared to natural seston, as well as a higher fecundity of $M$. minuta. The fecundity of $D$. birgei was significantly higher in the seston enriched with both $\mathrm{N}$ and $\mathrm{P}$. C, N, and P body content of cladocerans was similar to that of temperate counterparts; Conclusion: Energy limitation related to carbon content or food quality seems to be most important in controlling cladocerans' populations in the lake than food mineral content.
\end{abstract}

Keywords: mineral limitation, nitrogen, phosphorus, seston, tropical cladocerans.

Resumo: Objetivo: Foram realizados experimentos para avaliar o crescimento individual e a reprodução de cladóceros de uma lagoa marginal com a adição de nitrogênio $(\mathrm{N})$, fósforo (P) e fósforo e nitrogênio juntos ao séston natural; Métodos: Os experimentos foram realizados sazonalmente. Coortes originadas de fêmeas cultivadas foram submetidas aos seguintes tratamentos: 1) séston do lago, 2) séston do lago $+\mathrm{P}, 3$ ) séston do lago $+\mathrm{N}$ e 4) séston do lago + NP; Resultados: As razôes molares C:P e C:N do séston estavam sempre altas, de acordo com razóes estimadas para lagos temperados. A adição de $\mathrm{P}$ ao séston aumentou somente o crescimento de $D$. birgei. No entanto, a fecundidade de B. longirostris foi significativamente maior no tratamento do séston enriquecido com $\mathrm{N}$ comparado ao séston sem adiçóes, assim como a fecundidade de $M$. minuta. A fecundidade de $D$. birgei foi significantemente maior no séston enriquecido com $\mathrm{N}$ e P. O conteúdo corporal de $\mathrm{C}, \mathrm{N}$ e $\mathrm{P}$ dos cladóceros foi similar ao encontrado para cladóceros de regiáo temperada; Conclusáo: A limitação por energia relacionada ao conteúdo de carbono ou à qualidade do alimento parece ser mais importante no controle das populaçóes de cladóceros no lago comparado ao conteúdo mineral do alimento.

Palavras-chave: limitação mineral, nitrogênio, fósforo, séston, cladóceros tropicais.

\section{Introduction}

Marginal lakes are complex habitats and the mechanisms that drive their functioning are much debated, the annual hydrological variation of the river being assumed as the most important factor regulating these lakes (Junk, 1997). The lakes are fundamental for maintaining the biodiversity of floodplains, providing a great habitat variety for several aquatic organisms, including zooplankton, a common component of lakes. Furthermore, zooplankton composition from those lakes can be different from that found in the river and in the littoral region (Panarelli, 2004) since they are subjected to hydrological pulses.

Several environmental characteristics are known to control zooplankton populations, such as abiotic factors (Saunders and Lewis, 1988), food quantity 
and quality, competition, and predation (Gulati and DeMott, 1997). Food quality to zooplankton is related to the food content of C, N, P, lipids, essential fatty acids, proteins, and amino acids. Nitrogen is fundamental for the synthesis of amino acids and protein and phosphorus is involved in the synthesis of nucleic acids and, thus, is related to growth and reproduction.

In this context, a widely addressed issue is the mineral limitation of the phytoplankton to the zooplankton (Hessen, 1992, 2006, 2008; Urabe and Watanabe, 1992; Müller-Navarra, 1995). The mineral limiting hypothesis proposes that zooplankton can be limited by the nitrogen and phosphorus content of the food, phosphorus being most important in temperate regions and nitrogen in tropical regions (Lewis Jr., 1996; Talling and Lemoalle, 1998). Herbivores, like some Daphnia's species, maintain stoichiometric C:N and C:P ratios relatively constant even with considerable variation of $\mathrm{C}: \mathrm{N}$ and $\mathrm{C}: \mathrm{P}$ ratios of their diets (Hessen, 1990). Data from literature indicate that zooplanktonic C:N and C:P ratios are lower than those of phytoplankton (Hessen, 1990; Andersen and Hessen, 1991).

The sestonic elemental ratios vary widely among lakes (Hecky et al., 1993), specially C:P ratios, and several abiotic and biotic factors can be responsible for more than ten- fold variation of the seston C:P ratios (Hessen, 2006).

Several studies showed low values of individual growth and growth rates of Daphnia fed algae with low $\mathrm{P}$ content in relation to $\mathrm{C}$ (high C:P ratios) (Sommer, 1992; Sterner 1993; DeMott, 1998; Urabe et al., 1997; Elser et al., 2001) and low N content (Groeger et al., 1991). Conversely, some studies report a low correlation between Daphnia growth and $\mathrm{P}$ content in the field (Müller-Navarra, 1995) and in laboratory experiments using seston (DeMott and Tessier, 2002).

Zooplankton is a food resource for several taxonomic groups in marginal lakes, including invertebrates and fish larvae. Thus, population studies are of great importance to understand the community trophic structure of these ecosystems. Large floodplains areas have been modified or eliminated by the construction of dikes, channels and river bed rectifications, resulting in the reduction of studies about these areas (Junk, 1997). In the Equatorial region, the construction of reservoirs has also modified the flood pulse, upstream and downstream the reservoirs (Junk, 1997). The same is observed in Brazil, where several river basins have been altered by the construction of reservoirs (Tundisi et al., 2002) to attend the crescent energetic demand. Damming rivers can end in drastic ecological implications, because it implies in reduction of organic matter, energy and nutrients (Henry, 2003).

Several studies on zooplankton have been carried out in the lakes of a tropical river, at the confluence of Paranapanema River and Jurumirim Reservoir, São Paulo State, Brazil, where lakes are submitted to flood pulses (Casanova and Henry, 2004; Martins and Henry, 2004; Panarelli et al., 2003; De Nadai and Henry, 2009; Panarelli et al., submitted). However, laboratory experiments specially designed to evaluate relationships between planktonic herbivores and food quantity and quality are scarce in lentic environments subject to flood pulses.

The aim of this study was to test responses of cladocerans from Lake Camargo to additions of $\mathrm{N}, \mathrm{P}$, and both $\mathrm{N}$ and $\mathrm{P}$ to seston to find out whether mineral limitation holds for those tropical cladocerans. To achieve these objectives, the following analyses and experiments were performed: a) in vitro experiments for evaluating growth and reproduction of cladocerans fed natural seston and seston enriched with nutrients and b) elemental analyses of $\mathrm{C}, \mathrm{N}$, and $\mathrm{P}$ of seston and cladocerans.

\section{Material and Methods}

\subsection{Study site}

Camargo Lake (2330' $10^{\prime \prime} \mathrm{S}$ and $48^{\circ} 42^{\prime} 35^{\prime \prime} \mathrm{W}$ ) is a lake located near the confluence of Paranapanema River and Jurumirim Reservoir, in the Southwest of São Paulo State, Brazil. The lake is submitted to an annual water level variation around $2.7 \mathrm{~m}$ (Henry, 2009). The region is characterized by two seasons: cool-dry (April to October) and warm-wet (November to March). The lake is permanently connected to the river, except during prolonged dry periods (Henry et al., 2005). It is a shallow (maximum depth $=3.9 \mathrm{~m}$; mean depth $=3.2 \mathrm{~m}$ ), continuous polymictic lake with microstratifications in the afternoon and isothermy in the morning (Moschini-Carlos et al., 1999), indicating that it circulates at night due to its shallowness and the wind action. Total nitrogen and phosphorus ranged from 63-411 $\mu \mathrm{g} . \mathrm{L}^{-1}$ and from $13-63 \mu \mathrm{g} . \mathrm{L}^{-1}$, respectively, in the upper layers during 2002-2003. Phytoplankton is primarily composed of Cryptophyceae (Chroomonas spp. and Cryptomonas brasiliensis), followed by Chlorophyceae and Bacillariophyceae (Henry et al., 2006), densities ranging from 435 to 7710 ind. $\mathrm{mL}^{-1}$. Ceriodaphnia 
cornuta rigaudi and Diaphanosoma birgei were monthly recorded in the lake from 2000 to 2001. Bosminopsis deitersi, Bosmina hagmanni, and Moina minuta can also reach high abundances (Panarelli, 2004). Production of B. longirostris and D. birgei, in January/01 (wet-warm season), was respectively 6,050 and 22,020 $\mu \mathrm{g}$ DW.m ${ }^{-3}$.day ${ }^{-1}$; and in July/01 (cool-dry season) 391.9 and 517.2 $\mu \mathrm{g} \mathrm{DW} . \mathrm{m}^{-3}$.day ${ }^{-1}$, respectively (Panarelli et al., submitted).

\subsection{Cladocerans and alga cultures}

The cladocerans used in all experiments were isolated from Camargo Lake. The animals were collected using a plankton net $(50 \mu \mathrm{m})$ by vertical hauls, through the entire water column. The species were separated under a stereomicroscope and cultivated in the laboratory in $600 \mathrm{~mL}$ beakers containing filtered lake water (glass fiber filtersMillipore AP 40) with the addition of $1 \mathrm{mg} . \mathrm{L}^{-1}$ of Scenedesmus spinosus $\mathrm{R}$. Chodat (14 $\mu \mathrm{m}$ length). The chlorophycean was grown in batch cultures using modified MBL medium (Stemberger, 1981) in an environmental chamber (Eletrolab - model 100G) with constant aeration, temperature $\left(23^{\circ} \mathrm{C}\right)$ and a 12:12 hours dark/light photoperiod.

Animals were cultivated for several generations prior the experiments at constant temperature $\left(24^{\circ} \mathrm{C}\right)$ and a 12:12 hours dark/light photoperiod.

\subsection{Seston samplings and phytoplankton analysis}

Natural seston offered as food for cladocerans was obtained in the water column of the lake, using a motorized pump (Sthill). The lake water was first filtered in a $140 \mu \mathrm{m}$ net to exclude large zooplankton.

Phytoplanktonic algae were enumerated following Utermöhl's method (1958), the biovolume estimated by geometric forms best fitting each alga shape based on Wetzel and Likens (1991) and Hillebrand et al. (1999). The carbon content of the algae was assumed to be $10 \%$ of the biovolume (Vollenweider, 1974). Phytoplankton was divided in two size fractions, one considered edible $(\leq 36 \mu \mathrm{m})$ and the other inedible $(>36 \mu \mathrm{m})$ to cladocerans. Species composition and morphological characteristics of algae were analyzed and the results presented as density and biomass.

\subsection{Seston and the elemental composition of cladocerans}

Aliquots of seston used in the experiments were taken for chemical analyses to separate food quantitative effects (carbon content) from qualitative effects (phosphorus and nitrogen content). For analyzing particulate organic carbon (POC), phosphorus (P), and nitrogen $(\mathrm{N})$, samples (300-400 mL) were filtered in pre-ignited glass-fiber filters (Millipore AP40). POC was analyzed according to Strickland and Parsons (1972), P by the molybdate method (Murphy and Riley 1962), and nitrogen by the classic Kjeldahl method (Mackereth et al., 1978).

Non egg-bearing adult females of Bosmina longirostris, D birgei, and $M$. minuta from cultures were separated under a stereomicroscope and placed on glass slides and dried at $60{ }^{\circ} \mathrm{C}$ for 24 hours, being transferred to previously weighed tin capsules. Particulate $\mathrm{C}$ and $\mathrm{N}$ of the animals were evaluated on an elemental analyzer (Carlo-Erba CHN 1110). The analyses of particulate $\mathrm{P}$ were made according to Murphy and Riley (1962).

\subsection{Growth experiments}

Four growth experiments were performed using the most abundant cladoceran species in the lake during the period of each experiment, which are summarized in Table 1.

Seven individuals born within 24 hours were placed in $250 \mathrm{~mL}$-bottles, attached to a plankton wheel, rotating 1 minute every 15 minutes. Treatments, with three replicates each, were: 1) lake seston, 2) lake seston $+50 \mu \mathrm{PO}_{4}^{-} \mathrm{P} \mathrm{L}^{-1}$, 3) lake seston $+1,600 \mu \mathrm{g} \mathrm{NO}_{3}^{-} \mathrm{L}^{-1}$, and 4) lake seston $+50 \mu \mathrm{gO}_{4}^{-} \mathrm{PL}^{-1}+1,600 \mu \mathrm{g} \mathrm{NO}_{3}^{-} \mathrm{L}^{-1}$. The experiments were undertaken at the temperature of $24^{\circ} \mathrm{C}$ and 12: 12 hours photoperiod cycle.

Before starting the experiments, 10 neonates were placed on small, pre-tared pieces of aluminum foil, dried at $60^{\circ} \mathrm{C}$ for 24 hours to determine the initial body weight. In the subsequent days (2, 3, or 5), depending on the duration of the juvenile period of each species, the remaining animals were taken from each bottle, placed on glass slides, measured, dried

Table 1. Summary of the experiments.

\begin{tabular}{cccc}
\hline Experiment & Date & $\begin{array}{c}\text { Cladoceran/ } \\
\text { maximum length }(\mathrm{mm})\end{array}$ & Treatments \\
\hline I & $12-17 / 04 / 2007$ & B. longirostris $(0.40)$ & lake seston; lake seston + P; \\
II & $27 / 05-01 / 06 / 2007$ & D. birgei $(0.88)$ & lake seston + N; and \\
III & $24-28 / 01 / 2008$ & M. minuta $(0.67)$ & lake seston +NP \\
IV & $29 / 05-02 / 02 / 2008$ & M. minuta $(0.67)$ & \\
\hline
\end{tabular}


at $60{ }^{\circ} \mathrm{C}$ for 24 hours, and weighed for biomass evaluation. The biomass was evaluated by weighing the animals on a microbalance (Mettler Toledo UMT-2) to the nearest $0.1 \mu \mathrm{g}$. The exponential growth rate was calculated by the Equation 1 .

$$
\mathrm{g}=\left[\ln \left(\mathrm{W}_{\mathrm{t}}\right)-\ln \left(\mathrm{W}_{0}\right)\right] / \mathrm{t}
$$

where: $\mathrm{W}_{0}$ and $\mathrm{W}_{\mathrm{t}}$ are the average weight of the animals in time 0 and after $t$ days (3-5 days depending on the juvenile period of each species tested), respectively.

Only the juvenile growth was monitored but experiments were extended to evaluate the fecundity (eggs/total female) and clutch size.

The results were analyzed by General Linear Model (Estimate Model) and the significant differences by ANOVA (Systat Program) and post hoc Tukey test (Systat ${ }^{\oplus}$, version 9, 1999, SPSS, Chicago, IL, USA).

\section{Results}

\subsection{Seston and the elemental composition of cladocerans}

The elemental composition of natural lake seston and of seston enriched with nutrients used in the growth experiments is summarized in Table 2 . $P$ additions significantly increased its concentrations in the seston, except in Experiment III and in the end of Experiment IV. $\mathrm{N}$ additions also increased its concentrations in the seston, except in Experiments III and IV. The additions of both $\mathrm{N}$ and $\mathrm{P}$ increased the nutrient concentrations in the seston in most occasions. The C:P ratios were usually high and in most cases $\mathrm{P}$ additions significantly reduced their values, except in Experiments III and IV. The C:N ratios were also high, but $\mathrm{N}$ additions did not reduce their concentrations in the seston during

Table 2. Carbon, nitrogen and phosphorus concentrations and C:N and C:P ratios (molar) of the seston offered to cladocerans during the experiments I to VI. Data are means \pm SD for three replicates. Asterisks indicate significant differences (ANOVA, $\mathrm{p} \leq 0.05$ ).

\begin{tabular}{|c|c|c|c|c|c|c|c|}
\hline Experiments & & & $\mathrm{C}\left(\mathrm{mg} \cdot \mathrm{L}^{-1}\right)$ & $\mathrm{N}\left(\mathrm{mg} \cdot \mathrm{L}^{-1}\right)$ & $P\left(\mu g . L^{-1}\right)$ & $C: P$ & C:N \\
\hline \multirow[t]{8}{*}{ I } & \multirow[t]{4}{*}{ Initial } & Seston & $5.36 \pm 0.06$ & $0.15 \pm 0.01$ & $7.65 \pm 0.15$ & $1868.00 \pm 10.40$ & $42.00 \pm 3.00$ \\
\hline & & Seston $+P$ & $5.30 \pm 0.15$ & na & $25.50 \pm 0.70^{*}$ & $554.00 \pm 6.80^{*}$ & na \\
\hline & & Seston $+\mathrm{N}$ & $5.45 \pm 0.17$ & $0.24 \pm 0.02^{*}$ & na & na & $27.0 \pm 0.50^{*}$ \\
\hline & & Seston + NP & $7.10 \pm 0.05$ & $0.16 \pm 0.10$ & $28.00 \pm 1.40^{*}$ & $680.50 \pm 48.70^{*}$ & $55.00 \pm 5.00$ \\
\hline & \multirow[t]{4}{*}{ Final } & Seston & $5.30 \pm 0.10$ & $0.15 \pm 0.10$ & $8.00 \pm 0.00$ & $1755 \pm 30.90$ & $41.00 \pm 4.00$ \\
\hline & & Seston + P & $5.40 \pm 0.14$ & na & $25.50 \pm 2.10^{*}$ & $570.00 \pm 15.70^{*}$ & na \\
\hline & & Seston $+\mathrm{N}$ & $5.50 \pm 0.35$ & $0.12 \pm 0.02$ & na & na & $55.00 \pm 12.00$ \\
\hline & & Seston + NP & $7.30 \pm 0.07$ & $0.23 \pm 0.10^{*}$ & $30.00 \pm 1.40^{*}$ & $650.00 \pm 24.00^{*}$ & $32.00 \pm 0.80^{*}$ \\
\hline \multirow[t]{8}{*}{$\|$} & \multirow[t]{4}{*}{ Initial } & Seston & $4.50 \pm 0.10$ & $0.10 \pm 0.00$ & $6.10 \pm 0.50$ & $1960.00 \pm 95.10$ & $50.00 \pm 1.40$ \\
\hline & & Seston $+P$ & $4.80 \pm 0.20$ & na & $24.00 \pm 2.80^{*}$ & $536.00 \pm 66.10^{*}$ & na \\
\hline & & Seston $+\mathrm{N}$ & $4.50 \pm 0.00$ & $0.19 \pm 0.02^{*}$ & na & na & $27.30 \pm 3.50$ * \\
\hline & & Seston + NP & $6.40 \pm 0.00$ & $0.26 \pm 0.10^{*}$ & $30.50 \pm 2.10^{*}$ & $560.40 \pm 38.95^{*}$ & $23.00 \pm 8.85^{*}$ \\
\hline & \multirow[t]{4}{*}{ Final } & Seston & $4.90 \pm 0.07$ & $0.18 \pm 0.09$ & $8.60 \pm 2.20$ & $1582.20 \pm 420.65$ & $35.00 \pm 16.00$ \\
\hline & & Seston + P & $4.85 \pm 0.10$ & na & $21.50 \pm 3.50^{*}$ & $608.85 \pm 103.00^{*}$ & na \\
\hline & & Seston + N & $4.90 \pm 0.10$ & $0.11 \pm 0.01$ & na & na & $50.60 \pm 4.70$ \\
\hline & & Seston + NP & $6.75 \pm 0.00$ & $0.20 \pm 0.02$ & $26.00 \pm 4.25^{*}$ & $700.00 \pm 114.70^{*}$ & $39.90 \pm 3.30$ \\
\hline \multirow[t]{8}{*}{ III } & \multirow[t]{4}{*}{ Initial } & Seston & $5.75 \pm 0.07$ & $0.11 \pm 0.01$ & $12.90 \pm 3.50$ & $1230.00 \pm 320.00$ & $59.00 \pm 6.00$ \\
\hline & & Seston $+P$ & $8.20 \pm 0.07$ & $0.11 \pm 0.04$ & $14.00 \pm 3.50$ & $1620.00 \pm 380.00$ & $88.00 \pm 25.00$ \\
\hline & & Seston $+N$ & $8.10 \pm 0.10$ & $0.11 \pm 0.01$ & $16.00 \pm 4.00$ & $1390.00 \pm 330.00$ & $83.00 \pm 8.00$ \\
\hline & & Seston + NP & $7.85 \pm 0.09$ & $0.26 \pm 0.03^{*}$ & $19.00 \pm 4.50$ & $1116.00 \pm 270.00$ & $36.00 \pm 4.00^{*}$ \\
\hline & \multirow[t]{4}{*}{ Final } & Seston & $5.30 \pm 0.10$ & $0.15 \pm 0.04$ & $13.00 \pm 2.00$ & $1100.00 \pm 190.00$ & $43.00 \pm 13.00$ \\
\hline & & Seston $+P$ & $7.90 \pm 0.03$ & $0.10 \pm 0.04$ & $14.50 \pm 2.00$ & $1460 \pm 140.00$ & $106.00 \pm 52.00$ \\
\hline & & Seston $+N$ & $8.40 \pm 0.14$ & $0.10 \pm 0.01$ & $13.00 \pm 0.20$ & $1675.00 \pm 48.00$ & $102.00 \pm 11.00$ \\
\hline & & Seston + NP & $8.10 \pm 0.05$ & $0.17 \pm 0.05$ & $13.00 \pm 0.90$ & $1620.00 \pm 119.00$ & $56.00 \pm 16.00$ \\
\hline \multirow[t]{8}{*}{ IV } & \multirow[t]{4}{*}{ Initial } & Seston & $5.70 \pm 0.20$ & $0.19 \pm 0.05$ & $14.75 \pm 0.00$ & $1030.00 \pm 34.00$ & $36.00 \pm 10.00$ \\
\hline & & Seston + P & $7.80 \pm 0.12$ & $0.10 \pm 0.00$ & $22.70 \pm 0.02^{*}$ & $916.00 \pm 2.50$ & $86.50 \pm 0.20$ \\
\hline & & Seston $+N$ & $7.60 \pm 0.02$ & $0.11 \pm 0.01$ & $15.80 \pm 0.07$ & $1280.00 \pm 4.00$ & $78.50 \pm 9.00$ \\
\hline & & Seston + NP & $7.60 \pm 0.40$ & $0.13 \pm 0.02$ & $19.00 \pm 0.05^{*}$ & $1050.00 \pm 60.00$ & $69.50 \pm 5.00$ \\
\hline & \multirow[t]{4}{*}{ Final } & Seston & $7.90 \pm 0.40$ & $0.11 \pm 0.01$ & $15.40 \pm 1.70$ & $1375.00 \pm 89.00$ & $82.00 \pm 13.20$ \\
\hline & & Seston + P & $7.90 \pm 0.10$ & $0.11 \pm 0.00$ & $17.70 \pm 0.00$ & $1190.00 \pm 276.00$ & $81.00 \pm 12.00$ \\
\hline & & Seston $+N$ & $8.00 \pm 0.20$ & $0.10 \pm 0.00$ & $16.00 \pm 0.03$ & $1340.00 \pm 33.00$ & $89.00 \pm 2.00$ \\
\hline & & Seston + NP & $7.95 \pm 0.20$ & $0.16 \pm 0.07^{*}$ & $28.40 \pm 0.06^{*}$ & $746.00 \pm 22.00$ & $67.00 \pm 30.00$ \\
\hline
\end{tabular}


Experiments III and IV, but the addition of both $\mathrm{N}$ and $\mathrm{P}$ reduced C: $\mathrm{N}$ ratios in the beginning of Experiment III.

The carbon content of cladocerans varied from $38 \%$ in $M$. minuta to $41 \%$ in B. longirostris (Table 3). $\mathrm{N}$ content was similar among the three species, varying from 12 to $14 \%$. B. longirostris showed the lowest relative value of $\mathrm{P}$ content $(0.5 \%)$ and D. birgei and $M$. minuta presented similar values.

\subsection{Phytoplankton}

Phytoplankton was mainly composed of Cryptophyceae in the first three experiments and Bacillariophyceae in the fourth experiment (Figure 1).

Algae $\leq 36 \mu \mathrm{m}$ size predominated in density in all experiments. The size fraction $>36 \mu \mathrm{m}$ predominated in biomass in Experiment I, showing an almost equally contribution in Experiments II and IV and little contribution in Experiment III (Table 4).

Table 3. Relative content of carbon, nitrogen, and phosphorus of cladocerans from Lake Camargo.

\begin{tabular}{lccc}
\hline & $\mathrm{C}$ & $\mathrm{N}$ & $\mathrm{P}$ \\
\hline B. longirostris & $41.00 \pm 2.00$ & $14.00 \pm 0.20$ & $0.50 \pm 0.15$ \\
D. birgei & $40.00 \pm 1.00$ & $12.00 \pm 0.40$ & $1.30 \pm 0.05$ \\
M. minuta & $38.00 \pm 1.50$ & $12.00 \pm 2.50$ & $1.10 \pm 0.25$ \\
\hline
\end{tabular}

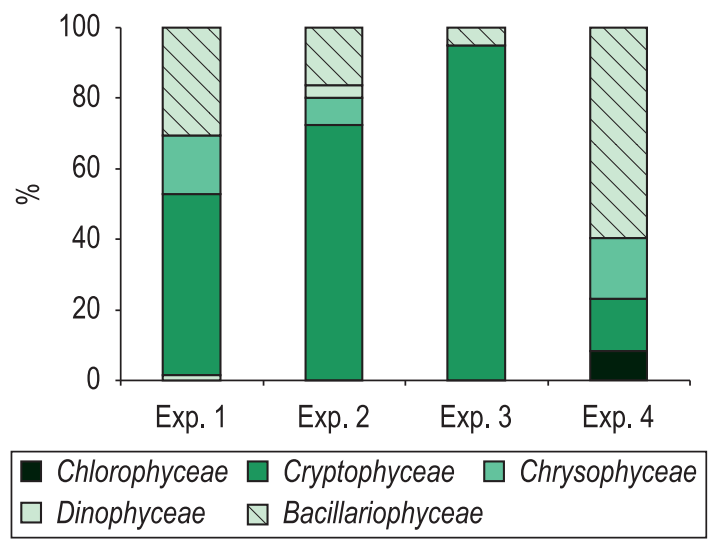

Figure 1. Relative density of phytoplankton in the seston during Experiments I to IV.
The predominant algae species, in density, were: Chroomonas spp., Cyclotella stelligera, Dinobryon bavaricum, Nitzchia acicularis, and Urosolenia longiseta in Experiment I. Chroomonas spp., D. bavaricum, and $N$. acicularis predominated in Experiment II. Again, Chroomonas spp., and also Cryptomonas sp., and Aulacoseira distans were the main algae species found in Experiment III. A colonial crysophycean, Synura uvella, followed by Chroomonas spp., Monoraphidium contortum, and $N$. acicularis dominated in Experiment IV. In biomass, $D$. bavaricum was the most abundant in Experiments I and II, Cryptomonas spp. and Chroomonas spp. in Experiment III, and Synura uvella in Experiment IV.

The total algal carbon contents were: 0.054, 0.034, 0.017, and $0.037 \mathrm{mg} \mathrm{C.L}^{-1}$, in experiments I, II, III, and IV, respectively.

\subsection{Growth bioassays}

The growth rates of $\mathrm{B}$. longirostris were significantly higher in the seston enriched with $\mathrm{N}$ compared to seston without additions (Figure 2). $D$. birgei showed significantly higher growth rates in the seston enriched with P. No significant differences among treatments were observed for $M$. minuta.

$D$. birgei presented a significantly higher fecundity in the seston enriched with $\mathrm{N}$ and $\mathrm{P}$, and M. minuta in the seston enriched with $\mathrm{N}$ compared to seston without additions (Figure 2).

\section{Discussion}

The enrichment of the seston with $\mathrm{N}$ and $\mathrm{P}$ showed low influence on growth rates and reproduction of cladocerans. Sinergic effect or colimitation of $\mathrm{N}$ and $\mathrm{P}$ was observed for $D$. birgei that presented higher fecundity in the seston enriched with $\mathrm{N}$ and P. Fileto et al. (2007) also observed higher growth rate of D. gessneri when both $\mathrm{N}$ and $\mathrm{P}$ were added to seston. Ferrão-Filho et al. (2003) found colimitation of $\mathrm{N}$ and $\mathrm{P}$ testing growth and reproduction of cladocerans in nutrient-deficient algae. The authors related the colimitation to a reduction of protein synthesis (enzymes) and accumulation of carbohydrates and

Table 4. Relative density and biomass of algae $\leq 36 \mu \mathrm{m}$ and $>36 \mu \mathrm{m}$ in the seston during the experiments.

\begin{tabular}{|c|c|c|c|c|c|c|c|c|}
\hline \multirow[t]{2}{*}{ Experiment } & \multicolumn{2}{|c|}{ I } & \multicolumn{2}{|c|}{ II } & \multicolumn{2}{|c|}{ III } & \multicolumn{2}{|c|}{ IV } \\
\hline & $\leq 36 \mu \mathrm{m}$ & $>36 \mu \mathrm{m}$ & $\leq 36 \mu \mathrm{m}$ & $>36 \mu \mathrm{m}$ & $\leq 36 \mu \mathrm{m}$ & $>36 \mu \mathrm{m}$ & $\leq 36 \mu \mathrm{m}$ & $>36 \mu \mathrm{m}$ \\
\hline Density & 74.0 & 26.0 & 84.0 & 16.0 & 99.0 & 1.0 & 85.0 & 15.0 \\
\hline Biomass & 31.0 & 69.0 & 51.0 & 49.0 & 98.0 & 2.0 & 56.0 & 44.0 \\
\hline
\end{tabular}



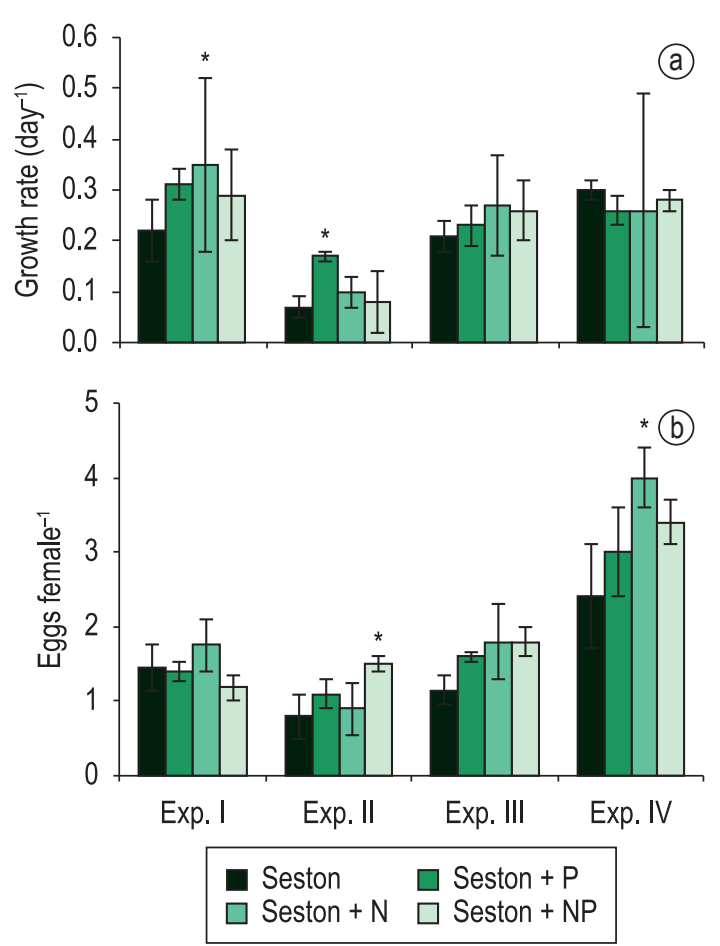

Figure 2. Growth rates (a) and fecundity (b) (means \pm $\mathrm{SD}$ ) of Bosmina longirostris, D. birgei and M. minuta in Experiments I to IV. Asterisks above bars indicate significant differences.

lipids in nutrient-deficient algae, as suggested in other studies.

The C:P and C: $\mathrm{N}$ ratios were always high during the present study, and since in the tropics limiting values have not yet been established and, thus, assuming the limits for temperate lakes, sestonic C:P and C:N ratios were limiting in Lake Camargo. Limiting C:P molar ratios estimated for temperate lakes range from 138 to 500 (Urabe and Watanabe, 1992; Sterner and Hessen 1994; DeMott and Gulati, 1999). C:N molar ratios ranging from 15 to 30 molar were suggested to lower food quality (Urabe and Watanabe, 1992). Particulate $P$ values in Lake Camargo are not low considering the conceptual model for $\mathrm{C}$ and P-limitation for Daphnia presented by Hessen (2008). However, as particulate $\mathrm{C}$ is very high in this lake, due to detritus resuspension, the values are in the range of C-saturation and P-limitation, according to Hessen (2008).

However, in Experiments III and IV, the addition of $\mathrm{N}$ and $\mathrm{P}$ to seston did not significantly enhance nutrient concentrations, except the $\mathrm{P}$ addition in the beginning of Experiment IV. Probably, algae were saturated by nutrients and did not absorb the added nutrients. $P$ concentrations of natural seston (before additions) were also higher when compared to Experiments I and II. Therefore, no effects due to seston enrichment on cladocerans growth and reproduction were expected. In Experiment III, seston was dominated by small cryptophyceans, in density and in biomass (mainly the small and rounded Chroomonas spp.), which are considered a high quality food owing to the elevated content of PUFAs (polyunsaturated fatty acids) (Brett and Müller-Navarra, 1997). Thus, seston was composed of highly nutritive food and the addition of $\mathrm{N}$ and $\mathrm{P}$ did not improve or constrain the growth and reproduction of cladocerans. In Experiment IV, the fecundity of $M$. minuta was significantly higher in the seston enriched with N. Seston during this experiment was dominated, in density and biomass, by algae smaller than $36 \mu \mathrm{m}$, with a high contribution of Bacillariophyceae (mainly $N$. acicularis) and the crysophycean $S$. uvella, that forms small colonies (GALD $=17 \mu \mathrm{m})$. Similarly to diatoms, cryptophyceans are also rich in PUFAs. Therefore, the elevated fecundity was probably more related to food aspects other than mineral content, since although a higher fecundity in the seston enriched with $\mathrm{N}$ was observed, its addition did not enhance seston nitrogen concentration.

Negative effects of high C:P ratios on Daphnia growth have been reported (Urabe et al., 1997; Elser et al., 2001; DeMott and Pape, 2005). In contrast, some studies have found low correlation between Daphnia growth and sestonic P content (Müller-Navarra, 1995; DeMott and Tessier, 2002). Negative effect of $\mathrm{P}$ addition to seston has been observed on population growth of Ceriodaphnia dubia (Matveev and Balseiro, 1990). Fileto et al. (2007) found that cladocerans did not respond to $\mathrm{P}$ addition, but responded to the additions of both $\mathrm{N}$ and P. Fileto et al. (in press) observed that despite high C:P and C:N ratios, cladocerans from Lake Camargo were able to grow and reproduce in experiments testing different food size fractions. Elser et al. (2000) studying the possible influence of P limitation on Daphnia found that ca. 22\% of the sestonic P:C ratios are higher than the proposed threshold elemental ratios (TER) for $\mathrm{P}$ that corresponds to $0.43 \% \mathrm{P}$, considering that $\mathrm{C}$ is $50 \%$ of the dry mass. Variation of P:C above the TER is irrelevant to animals' performance (Boersma and Elser, 2006). Probably, abiotic factors such as temperature, associated to algae features, like size, shape, and mucilaginous sheaths had stronger influence on growth and reproduction of cladocerans.

Most of the energy (C) contained in the lake seston and used as food by zooplanktonic 
populations is mainly composed of detritus, algal carbon usually contributing a lower amount. However, several aquatic organisms are able to feed also on detritus and bacteria, besides phytoplankton (Azam et al., 1983).

The contribution of phytoplankton to total sestonic C is usually low, rarely exceeding $40 \%$ (Hessen et al., 2003). In the present study, algal carbon values were $\leq 1.0 \%$, and most of the sestonic carbon was composed of detritus, bacteria and microzooplankton. In Experiment III, algal carbon concentration $\left(0.017 \mathrm{mg} \mathrm{C}^{-\mathrm{L}^{-1}}\right)$ was within the threshold food concentration $\left(<0.025 \mathrm{mg} \mathrm{C}^{-1} \mathrm{~L}^{-1}\right)$ found for tropical cladocerans by Bunioto and Arcifa (2007). However, M. minuta was able to grow and reproduce, reinforcing the importance of other seston components in the diets of cladocerans. The low value of algal carbon in this experiment can be related to the high dominance of small cryptophyceans (Chroomonas sp. and Cryptomonas sp.).

Thus, in Lake Camargo, the non-algal sestonic fraction can be a food source to cladocerans, and originates from inputs from sediment resuspension and allochthonous material from the catchment area (Fileto et al., in press). The sediment resuspension interferes on light penetration, causing its decrease and favoring some planktonic groups such as cryptophyceans (Henry et al., 2006), which predominated during almost all experiments (except in Experiment IV where bacillariophyceans dominated). These small edible algae should favor cladocerans populations, but sometimes herbivores may be constrained by the high contribution of larger algae. In Experiments I and II, D. bavaricum, a large and colonial alga, predominated in biomass and $D$. birgei presented low growth rates and egg production whereas $B$. longirostris apparently was not affected, probably because of its capacity to avoid large algae. Spiny algae are hard to be handled by small species (Lampert, 1987) and colonies or large filaments can interfere in the filtration process or be rejected (Kurmayer, 2000). Fileto et al. (2004) observed that smaller cladocerans showed preference for nanoplankton $(\leq 20 \mu \mathrm{m})$ and one large species for microplankton $(>20 \mu \mathrm{m})$.

The $\mathrm{C}, \mathrm{N}$, and $\mathrm{P}$ body contents of cladocerans in the present study were similar to results from literature. Daphnia of temperate regions presents, on average, $44 \%$ of $\mathrm{C}$ body content (Hessen, 1990), $\mathrm{N}$ ranging from 8 to $10 \%$ in cladocerans (Andersen and Hessen, 1991). The P content, especially in Daphnia, ranges from 0.60 to $1.50 \%$
(Andersen and Hessen, 1991). In previous studies carried out by Fileto et al. (2007) similar values were also found: C content of C. richardi, D. ambigua, and D. gessneri varied from 48.55 to $52.40 \%, \mathrm{P}$ content from 0.99 to $1.30 \%$, and $\mathrm{N}$ from 7.10 to $11.75 \%$. B. longirostris presented the lowest values of $\mathrm{P}$ content in the present study and similar results (ca. $0.7 \%$ ) have been reported by Hessen and Lyche (1991). Bosmina is known to present a low $\mathrm{P}$ content, which was supposed to be indicative of a lower P requirement than Daphnia, a higher efficiency on processing phosphorus or a better ability to survive losses in body P content (Schulz and Sterner, 1999). Differences in P content among species could be related to variation in RNA content (Mckee and Knowles, 1987).

Lake Camargo is highly affected by hydrological pulses (Henry, 2005). The phytoplankton composition is maintained in a successional stage due to disturbances in the lake, being dominated by small and fast-growing species such as cryptophyceans and diatoms, some of them resuspended from the bottom (Granado et al., 2009). Zooplankton species should be adapted to survive under food limitation in this kind of disturbed environment. Carbon limitation is uncommon, but can occur at least during some parts of the year, because sestonic carbon can be predominantly composed of low quality or unsuitable food sources for most herbivores. Shape, size and other algae features, can constrain herbivores, contributing to decrease carbon uptake, and interfering with processes, enhancing their energy expenditures.

Our findings support the idea that in the tropical region, mineral limitation is unlikely and that sestonic C:P and C: $\mathrm{N}$ ratios can be distorted by the high amount of detritus and other carbon sources in shallow lakes, resulting in that high values are not necessarily indicative of sestonic stoichiometric limitation for herbivores.

\section{Acknowledgements}

We thank FAPESP (São Paulo State Foundation for Research Support) for a grant to C. Fileto (2005/50278-9), the personnel of the Limnology Lab for helping in the field, and Fabiana Akemi Kudo for helping in the nitrogen analyses.

\section{References}

ANDERSEN, T. and HESSEN, DO., 1991. Carbon, nitrogen, and phosphorus content of freshwater zooplankton. Limnology and Oceanography, vol. 36, no. 4 , p. $807-814$. 
AZAM, F., FENCHEL, T., FIELD, JG., GRAY, JS., MEYER-REIL, LA. and THINGSTAD, F., 1983. The ecological role of Water-column microbes in the sea. Marine Ecology Progress Series, vol. 10, p. 257-263.

BRETT, MT. and MÜLLER-NAVARRA, DC., 1997. The role of highly unsaturated fatty acids in aquatic food web processes. Freshwater Biology, vol. 38, p. 483-499.

BUNIOTO, TC. and ARCIFA, MS., 2007. Effects of food limitation and temperature on cladocerans from a tropical Brazilian lake. Aquatic Ecology, vol. 41, p. 569-578.

CASANOVA, SMC. and HENRY, R., 2004. Longitudinal distribution of Copepoda populations in the transition zone of Paranapanema River and Jurumirim Reservoir (São Paulo, Brazil) and interchange with two lateral lakes. Brazilian Journal of Biology, vol. 64, no. 1, p. 11-26.

DE NADAI, R. and HENRY, R., 2009. Temporary fragmentation of a marginal lake and its effects on zooplankton community structure and organization. Brazilian Journal of Biology, vol. 69, no. 3, p. 819-835.

DEMOTT, WR., 1998. Utilization of a cyanobacterium and a phosphorus-deficient green algae as complementary resources by daphnids. Ecology, vol. 79, no. 7, p. 2463-2481.

DEMOTT, WR. and GULATI, RD., 1999. Phosphorus limitation in Daphnia: Evidence from a long-term study of three hypereutrophic Dutch lakes. Limnology and Oceanography, vol. 44, no. 6, p. 1557-1564.

DEMOTT, WR. and TESSIER, AJ., 2002. Stoichiometric constraints vs. algal defenses: testing mechanisms of zooplankton food limitation. Ecology, vol. 83, no. 12, p. 3426-3433.

DEMOTT, WR. and PAPE, BJ., 2005. Stoichiometry in an ecological context: testing for links between Daphnia P-content, growth rate and habitat preference. Oecologia, vol. 142, p. 20-27.

ELSER, JJ., FAGAN, WF., DENNO, RF., DOBBERFUHL, DR., FOLARIN, A., HUBERTY, A., INTERLANDI, S., KILHAM, SS., MCCAULEY, E., SCHULZ, KL., SIEMANN, EH. and STERNER, RW., 2000. Nutritional constraints in terrestrial and freshwater food webs. Nature, vol. 408, p. $578-580$.

ELSER, JJ., HAYAKAWA, K. and URABE, J., 2001. Nutrient limitation reduces food quality for zooplankton: response to seston phosphorus enrichment. Ecology, vol. 82, no. 3, p. 898-903.

FERRÃO FILHO, AS., FILETO, C., LOPES, NP. and ARCIFA, MS., 2003. Effects of essential fatty acids and $\mathrm{N}$ and P-limited algae on the growth rate of tropical cladocerans. Freshwater Biology, vol. 48, no. 5 , p. $759-767$.
FERRÃO FILHO, AS., TESSIER, AJ. and DEMOTT, WR., 2007. Sensitivity of herbivorous zooplankton to phosphorus deficient diets: testing stoichiometric theory and the growth rate hypothesis. Limnology and Oceanography, vol. 52, no. 1, p. 407-415.

FILETO, C., ARCIFA, MS., FERRÃO FILHO, AS. and SILVA, LHS., 2004. Influence of phytoplankton fractions on growth and reproduction of tropical cladocerans. Aquatic Ecology, vol. 38, p. 503-514.

FILETO, C., ARCIFA, MS. and SILVA, LHS., 2007. Testing mineral food quality for tropical cladocerans from a shallow Brazilian lake. Acta Limnologica Brasiliensia, vol. 19, no. 3, p. 257-271.

FILETO, C., ARCIFA, MS., HENRY, R. and FERREIRA, RAR. (in press). Effects of temperature, sestonic algae features, and seston mineral content on cladocerans of a tropical lake. Annales de Limnologie - International Journal of Limnology.

GRANADO, DC., HENRY, R. and TUCCI, A., 2009. Influência da variação do nível hidrométrico na comunidade fitoplanctônica do Rio Paranapanema e de uma lagoa marginal na zona de desembocadura na Represa de Jurumirim (SP). Hoehnea, vol. 36, no. 1, p. 113-129.

GROEGER, AW., SCHARAM, MD. and MARZOLF, GR., 1991. Influence of food quality on growth and reproduction in Daphnia. Freshwater Biology, vol. 26, no. 1, p. 11-19.

GULATI, RD. and DEMOTT, WR., 1997. The role of food quality for zooplankton: remarks on the stateof-the-art, perspectives and priorities. Freshwater Biology, vol. 38, no. 3, p. 753-768.

HECKY, RE., CAMPBELL, P. and HENDZEL, LL., 1993. The stoichiometry of carbon, nitrogen, and phosphorus in particulate matter of lakes and oceans. Limnology and Oceanography, vol. 38, no. 4, p. 709-724.

HENRY, R., 2003. Os ecótonos nas interfaces dos Ecossistemas Aquáticos. São Carlos: Rima. 349 p.

HENRY, R., 2005. The connectivity of the Paranapanema River with two lateral lakes in its mouth zone into the Jurumirim Reservoir. Acta Limnologica Brasiliensia, vol. 17, no. 1, p. 57-69.

HENRY, R., PANARELLI, EA., CASANOVA, SMC., SUIBERTO, MR. and AFONSO, AAO., 2005. Interaçôes hidrológicas entre lagoas marginais e o rio Paranapanema na zona de sua desembocadura na represa de Jurumirim. In NOGUEIRA, MG., HENRY, R. and JORCIN, A. (Eds.). Ecologia de reservatórios: impactos potenciais açóes de manejo e sistemas em cascata. São Carlos: Rima. p. 57-82.

HENRY, R., USHINOHAMA, E. and FERREIRA, RMR., 2006. O fitoplâncton em três lagoas e no Rio Paranapanema na zona de sua desembocadura na Represa de Jurumirim durante um período 
prolongado de seca. Revista Brasileira de Botânica, vol. 29 , no. 3, p. 399-414.

HENRY, R., 2009. Annual changes in sediment entrapment efficiency in lakes lateral to a river (Paranapanema River, São Paulo, Brazil). Acta Limnologica Brasiliensia, vol. 21, no. 1, p. 25-34.

HESSEN, DO., 1990. Carbon, nitrogen and phosphorus status in Daphnia at varying food conditions. Journal of Plankton Research, vol. 12, no. 6, p. 1239-1249.

HESSEN, DO. and LYCHE, A., 1991. Inter and intra-specific variations in zooplankton elemental composition. Archiv fur Hydrobiologie, vol. 121, p. 343-353.

HESSEN, DO., 1992. Nutrient element limitation of zooplankton production. The American Naturalist, vol. 140, no. 5, p. 799-814.

HESSEN, DO., ANDERSEN, T., BRETTUM, P. and FAAFENG, BA., 2003. Phytoplankton contribution to seston mass elemental ratios in lakes: implications for zooplankton nutrition. Limnology and Oceanography, vol. 48, no. 3, p. 1289-1296.

HESSEN, DO., 2006. Determinants of seston C:P - ratios in lakes. Freshwater Biology, vol. 51, p. 1560-1569.

HESSEN, DO., 2008. Efficiency, energy and stoichiometry in pelagic food webs; reciprocal roles of food quality and food quantity. Freshwater Biology, vol. 1, p. 43-57.

HILLEBRAND, H., DÜRSELEN, CD., KIRSCHTEL, D., POLLINGHER, D. and ZOHARY, T., 1999. Biovolume calculation for pelagic and benthic microalgae. Journal of Phycology, vol. 35, p. 403-424.

JUNK, WJ., 1997. The Central Amazon floodplain: ecology of a pulsing system. Berlim: Springer-Verlag. $525 \mathrm{p}$.

KURMAYER, R., 2000. Nutritive vs. interfering effects of Anabaena on Daphnia and Ceriodaphnia. Verhandlungen des Internationalen Verein Limnologie, vol. 27, p. 1-4.

LAMPERT, W., 1987. Laboratory studies on zooplankton-cyanobacteria interactions. New Zealand Journal of Marine and Freshwater Research, vol. 21, p. 483-490.

LEWIS Jr., WM., 1996. Tropical lakes: how latitude makes a difference. In SCHIEMAR, F. and BOLAND, KT. (Eds.). Perspectives in tropical limnology. The Netherlands: SPB Academic Publishers. p. 43-64.

MACKERETH, FJH., HERON, J. and TALLING, JF., 1978. Water analysis: some revised methods for limnologists. England: Freshwater Biological Association, Cumbria and Dorser. (Scientific Publication 36)

MATVEEV, VF. and BALSEIRO, EG., 1990. Contrasting responses of two cladocerans to changes in the nutritional value of nanoplankton. Freshwater Biology, vol. 23, no. 2, p. 197-204.

MCKEE, M. and KNOWLES, CO., 1987. Levels of protein, RNA, DNA, glycogen and lipids during growth and development of Daphnia magna Straus (Crustacea - Cladocera). Freshwater Biology, vol. 18, no. 2, p. 341-351.

MARTINS, GM. and HENRY, R., 2004. Composição e abundância do zooplâncton em três lagoas laterais ao rio Paranapanema na zona de sua desembocadura na Represa de Jurumirim (São Paulo). In CHELLAPA, NT., CHELLAPA, S. and PASSAVANTE, JZO. (Eds.). Ecologia Aquática Tropical. Natal: Editora Serv-Gráfica. p. 53-72.

MOSCHINI-CARLOS, V., POMPEO, MLM. and HENRY, R., 1999. Dinâmica da comunidade perifítica na zona de desembocadura do Rio Paranapanema, Represa de Jurumirim, SP. In HENRY, R. (Ed.). Ecologia de reservatórios: estrutura, função e aspectos sociais. Botucatu: Ed. Fapesp. p. 713-734.

MÜLLER-NAVARRA, D., 1995. Evidence that highly unsaturated fatty acids limits Daphnia growth in nature. Archiv fur Hydrobiologie, vol. 132, p. 297-307.

MURPHY, J. and RILEY, JP., 1962. A modified single solution method for the determination of phosphate in natural waters. Analytica Chimica Acta, vol. 27, p. 31-36.

PANARELLI, EA., CASANOVA, SMC., NOGUEIRA, MG., MITSUKA, PM. and HENRY, R. 2003. A comunidade zooplanctônica ao longo de gradientes longitudinais no Rio Paranapanema/Represa de Jurumirim (São Paulo, Brasil). In HENRY, R. (Ed.). Ecótonos nas interfaces dos ecossistemas aquáticos. São Carlos: Rima, p. 129-160.

PANARELLI, EA., 2004. Flutuaçôes mensais da comunidade zooplanctônica e dinâmica das populaçōes de Cladocera em lagoas marginais, na regiāo de transição Rio Paranapanema-Represa de Jurumirim (SP). Botucatu: Universidade Estadual Paulista. [Tese de Doutorado]

PANARELLI, EA., CASANOVA, SMC. and HENRY, R., (s.d.). Secondary production and biomass of Cladocera in two marginal lakes after the recovery of their hydrologic connectivity with a tropical river. Lakes \& Reservoirs: Research and Management (submitted)

SAUNDERS, JF. and LEWIS, WM., 1988. Composition and seasonality of the zooplankton of Lake Valencia, Venezuela. Journal of Plankton Research, vol. 10, no. 5, p. $957-985$.

SCHULZ, KL. and STERNER, RW., 1999. Phytoplankton phosphorus limitation and food quality for Bosmina. Limnology and Oceanography, vol. 44, no. 6, p. 1549-1556. 
SOMMER, U., 1992. Phosphorus-limited Daphnia: intraspecific facilitation instead of competition. Limnology and Oceanography, vol. 37, no. 5, p. 966-973.

STEMBERGER, RS., 1981. A general approach to the culture of planktonic rotifers. Canadian Journal of Fisheries and Aquatic Sciences, vol. 38, no. 6, p. 721-724.

STERNER, RW., 1993. Daphnia growth on varying quality of Scenedesmus: mineral limitation of zooplankton. Ecology, vol. 74, no. 8, p. 2351-2360.

STERNER, RW. and HESSEN, DO., 1994. Algal nutrient limitation and the nutrition of aquatic herbivores. Annual Review of Ecology and Systematica, vol. 25, p. 1-29.

STRICKLAND, JDH. and PARSONS, TR., 1972. $A$ practical handbook of seawater analysis. Canada. (Bulletin of Fisheries Research Board of Canada 167).

TALLING, JF. and LEMOALLE, J., 1998. Ecological dynamics of tropical inland waters. Cambridge: Cambridge University Press. 441 p.

TUNDISI, JG., MATSUMURA-TUNDISI, T. and ROCHA, O., 2002. Ecossistemas de águas interiores. In REBOUÇAS, AC., BRAGA, B. and TUNDISI,
JG. (Orgs.). Águas doces no Brasil: capital ecológico, usos e conservação. 2 ed. São Paulo: Escrituras. p. 153-194.

UTERMÖHL, V., 1958. Zur Vervollkommung der quantitativen Phytoplankton-Methodik. Verhandlungen Internationale Vereinigung fur Theoretische und Angewandte Limnologi, vol. 9, p. 1-38.

URABE, J. and WATANABE, Y., 1992. Possibility of nitrogen or phosphorus limitation for planktonic cladocerans: an experimental test. Limnology and Oceanography, vol. 37, no. 2, p. 244-251.

URABE, J., CLASEN, J. and STERNER, W., 1997. Phosphorus limitation of Daphnia growth: is it real? Limnology and Oceanography, vol. 42, no. 6, p. 1436-1443.

VOLLENWEIDER, RA., 1974. A manual on methods for measuring primary production in aquatic environments. 2 ed. Oxford: Blackwell Scientific Publications. 213 p. (IBP Handbook 12)

WETZEL, RG. and LIKENS, GE., 1991. Limnological analysis. 2 ed. New York: Springer-Verlag. 391 p.

Received: 11 December 2009 Accepted: 16 March 2010 